\section{New and emerging technologies for the treatment of inherited retinal diseases: a horizon scanning review}

J Smith', D Ward' ${ }^{1}$, M Michaelides ${ }^{2,3}$, AT Moore ${ }^{2,3}$ and S Simpson ${ }^{1}$

\begin{abstract}
The horizon scanning review aimed to identify new and emerging technologies in development that have the potential to slow or stop disease progression and/or reverse sight loss in people with inherited retinal diseases (IRDs). Potential treatments were identified using recognized horizon scanning methods. These included a combination of online searches using predetermined search terms, suggestions from clinical experts and patient and carer focus groups, and contact with commercial developers. Twenty-nine relevant technologies were identified. These included 9 gene therapeutic approaches, 10 medical devices, 5 pharmacological agents, and 5 regenerative and cell therapies. A further 11 technologies were identified in very early phases of development (typically phase I or pre-clinical) and were included in the final report to give a complete picture of developments 'on the horizon'. Clinical experts and patient and carer focus groups provided helpful information and insights, such as the availability of specialised services for patients, the potential impacts of individual technologies on people with IRDs and their families, and helped to identify additional relevant technologies. This engagement ensured that important areas of innovation were not missed. Most of the health technologies identified are still at an early stage of development and it is difficult to estimate when treatments might be available. Further, well designed trials that generate data on efficacy, applicability, acceptability, and costs of the technologies, as well as the longterm impacts for various conditions are required before these can be considered for adoption into routine clinical practice.
\end{abstract}

Eye (2015) 29, 1131-1140; doi:10.1038/eye.2015.115; published online 26 June 2015

\section{Introduction}

Inherited retinal diseases (IRDs) are a clinically and genetically heterogeneous group of disorders that together are an important cause of blindness. ${ }^{1}$ There are over 100 IRDs and the severity varies significantly. ${ }^{2}$ In England and Wales, IRD is the commonest cause of visual impairment registration in the working age population and a leading cause of childhood visual impairment. ${ }^{3-5}$ At least 4 of every 10000 children born in the UK will be diagnosed as severely visually impaired or blind by their first birthday, increasing to nearly 6 per 10000 by the age of 16 years. ${ }^{5}$ The causes of severe visual impairment and blindness are varied and complex, and at least three-quarters of children have disorders that are neither preventable nor treatable. ${ }^{5}$ Loss of sight in addition to the impact on the quality-of-life and emotional/

psychological well-being, also incurs significant costs for health and social services.

There is currently no cure for IRDs and new and more effective treatments are urgently needed. Management is focussed on accurate diagnosis, specialised genetic counselling, provision of information on prognosis, and strategies to improve the use of residual vision. Educational and social support is also important. Management is best provided as part of specialised multidisciplinary services, though the availability of such services varies throughout the UK, with some areas having no access at all. ${ }^{6}$ Treatment options are limited and are focused on visual rehabilitation, including the use of low vision aids, specialised computer
${ }^{1} \mathrm{NIHR}$ Horizon Scanning Centre, University of Birmingham, School of Health and Population Sciences, Birmingham, UK

${ }^{2} \mathrm{UCL}$ Institute of Ophthalmology, London, UK

${ }^{3}$ Moorfields Eye Hospital, London, UK

Correspondence: J Smith, NIHR Horizon Scanning Centre, University of Birmingham, School of Health and Population Sciences, Edgbaston, Birmingham B15 2TT, UK Tel: +44 (0)121414 7275. E-mail: j.l.j.smith@bham.ac.uk

Received: 24 February 2015 Accepted: 25 May 2015 Published online: 26 June 2015 
software, orientation, and mobility training. ${ }^{5}$ The provision of support for schooling and in the workplace is also very important. Eye clinic liaison officers (ECLOs) are an important source of support and provide advice on accessing services.

In 2012, a joint priority setting exercise was facilitated by the National Institute for Health Research (NIHR) James Lind Alliance (JLA, www.nets.nihr.ac.uk/ identifying-research/james-lind-alliance) in a process which brought together patients, carers, and clinicians to identify research questions and priorities relating to sight loss and vision. ${ }^{7}$ This partnership was initiated by the eye research charity Fight for Sight (www.fightforsight.org. uk). The subsequent Sight Loss and Vision Priority Setting Partnership (PSP) report was published in October 2013, one element of which highlighted key unanswered questions about the recognition and management of sight loss due to IRDs. ${ }^{6}$ Within this section, the report cites the specific question-'can a treatment to slow down progression or reverse sight loss in IRDs be developed?' as the agreed top priority for research into IRDs.

Following publication of the PSP report and discussions with Fight for Sight, the NIHR Horizon Scanning Centre (www.hsc.nihr.ac.uk) conducted a horizon scanning review that sought to identify new and emerging technologies in development that have the potential to slow or stop disease progression and/or reverse sight loss in people with IRDs. The NIHR Horizon Scanning Centre in conjunction with Fight for Sight aimed to use the results of this review to inform healthcare policy-makers, commissioners, researchers, research funders, clinicians, and patient groups about new therapies and advances 'on the horizon' that may be of relevance to the future of IRD management.

\section{Materials and methods}

A horizon scanning review aims to identify and present early information on all new and emerging technologies relevant to the topic area-of-interest. A review protocol was developed in close collaboration with Fight for Sight. To ensure relevant technologies were captured, treatments and therapies were included in the final review report if they had (or claimed to have) the potential to slow or stop disease progression and/or reverse sight loss in people with IRDs. These included:

- Pharmacological technologies-where these were in clinical trials with a relevant patient group and clinically relevant patient outcomes; typically phase II and III clinical trials.

- Medical technologies-where these were 'emerging' (expected to be CE marked and/or launched within the UK within $\sim 2$ years), 'new' (CE marked and usually only available for clinical use for less than one year), in the launch or early post-marketing stages, or 'new and poorly adopted' (that is, technologies within 2 years of launch and available in only two or three UK National Health Service (NHS) centres).

\section{Identification of technologies}

Between November 2013 and January 2014, potential treatments were identified using recognized horizon scanning methods. ${ }^{8}$ These included a combination of online searches (Table 1) using predetermined search terms (Table 2), suggestions from clinical experts, and patient and carer focus groups, and direct contact with commercial developers known to be active in this field. For technologies in development or in the early phases of adoption, it is common for there to be a lack of publicly accessible information and scientific data available; this is particularly true for non-pharmaceutical technologies. Where this was the case, further information about the technology was requested from the developers. This involved contacting commercial developers or research institutions directly using a standard information proforma. If no contact with the developer could be established, a focused internet search was conducted on the individual technology to obtain any information available.

\section{External input}

Ten clinical experts were identified, either through our initial scoping and literature searches, or proposed by Fight for Sight. The experts were contacted to ask whether they would act as review advisors, four of whom subsequently agreed. Experts were asked to provide information on new and emerging technologies already known to them and to provide comments on an initial list of relevant technologies identified, focusing on: innovativeness; potential for impact and acceptability; current availability and use within the UK NHS; and potential barriers to adoption.

Fight for Sight arranged and facilitated two patient and carer focus group discussions during which comments were sought on the potential impact on patients and acceptability of the identified technologies. The focus groups were held in March 2014 and were facilitated by a representative from the NIHR JLA and Fight for Sight. A representative from the NIHR Biomedical Research Centre at Moorfield's Eye Hospital took contemporaneous meeting notes. In total, 10 people attended; 5 men and 5 women; $60 \%$ were adults affected by IRDs (all aged over 40); 40\% were parents of children (aged between 4 and 15 years) with IRDs; conditions experienced by the participants included retinitis pigmentosa, Leber congenital amaurosis, Stargardt 
Table 1 Search protocol-identification sources

\begin{tabular}{|c|c|}
\hline Source name & Website \\
\hline \multicolumn{2}{|l|}{ Clinical trial and research registers } \\
\hline ClinicalTrials.gov & http://www.clinicaltrials.gov \\
\hline Current Controlled Trials & http://www.controlled-trials.com/mrct/ \\
\hline EU Clinical Trials Register & https://www.clinicaltrialsregister.eu/ \\
\hline NIHR Research Register & http://www.nihr.ac.uk/databases/Pages/default.aspx \\
\hline WHO International Clinical Trials Registry & http://www.who.int/trialsearch/Default.aspx \\
\hline \multicolumn{2}{|l|}{ Media and industry news } \\
\hline Clinica MedTech Intelligence & http://www.clinica.co.uk/ \\
\hline MedGadget & http://www.medgadget.com/ \\
\hline MEDICA & http://www.medica.de/ \\
\hline Medical News Today & http://www.medicalnewstoday.com/ \\
\hline \multicolumn{2}{|l|}{ Primary research and online libraries } \\
\hline Google Scholar & http://scholar.google.com/ \\
\hline Medline, Medline in Progress and EMBASE & http://www.elibrary.bham.ac.uk/ \\
\hline PubMed.gov & http://www.ncbi.nlm.nih.gov/entrez/query.fcgi?db=PubMed \\
\hline ZETOC British Library Database & http://zetoc.mimas.ac.uk/ \\
\hline \multicolumn{2}{|l|}{ Specialist sources } \\
\hline EuroStemCell & http:/ /www.eurostemcell.org/ \\
\hline London Project to Cure Blindness & www.thelondonproject.org \\
\hline Moorfields Eye Hospital Trust & http://www.moorfields.nhs.uk/Home \\
\hline NIHR Rare Diseases Translational Research Collaboration & $\begin{array}{l}\text { https://www.gov.uk/government/publications/rare-diseases- } \\
\text { strategy }\end{array}$ \\
\hline Retina Journal & http://journals.lww.com/retinajournal/Pages/default.aspx \\
\hline The European Blind Union & http://www.euroblind.org \\
\hline \multicolumn{2}{|l|}{ Technology-based sources } \\
\hline Adis Insight & http://bi.adisinsight.com/ \\
\hline Pharmaprojects & NA-subscription based source \\
\hline NIHR Horizon Scanning Centre & http://www.hsc.nihr.ac.uk/ \\
\hline \multicolumn{2}{|c|}{ Tertiary sources, horizon scanning and health technology assessment (HTA) agencies } \\
\hline $\begin{array}{l}\text { Australian Safety and Efficacy Register of New Interventional } \\
\text { Procedures }\end{array}$ & http:/ /www.surgeons.org \\
\hline Canadian Agency for Drugs and Technologies in Health & http://www.cadth.ca \\
\hline ECRI Institute & http://www.ecri.org \\
\hline EuroScan International Network & http://www.euroscan.org.uk \\
\hline Health Policy Advisory Committee on Technology & http://www.health.qld.gov.au/healthpact/html \\
\hline $\begin{array}{l}\text { International Network of Agencies for Health Technology } \\
\text { Assessment }\end{array}$ & http://www.inahta.org/HTA/Database/ \\
\hline NIHR Evaluation, Trials and Studies Coordinating Centre & www.netscc.ac.uk \\
\hline
\end{tabular}

macular dystrophy, and Usher syndrome. Of the children represented by their parents, one was blind, one severely visually impaired, and two at early stages of sight loss. Of the adult patients, two were totally blind, three visually impaired, and one still had good vision.

\section{Review output}

Technologies identified as in active development at the time of the review were included in the report; technologies no longer in development were excluded. The resulting output was a descriptive list of new and emerging technologies with the potential to slow or stop disease progression and/or reverse sight loss. No analysis of trial data or results obtained during the identification stages was carried out. The review advisors and representatives from Fight for Sight were also asked to review the finalized report prior to publication to ensure that the information included was accurate and that their comments and views were represented correctly.

\section{Results}

Twenty-nine new and emerging technologies were identified that had, or claim to have, the potential to slow or stop disease progression and/or reverse sight loss (Table 3). These included 9 gene therapeutic approaches, 10 medical devices, 5 pharmacological agents (drugs), and 
Table 2 Search terms

\begin{tabular}{l} 
Mesh headings \\
\hline Eye diseases, hereditary; retinal diseases \\
Inherited retinal diseases \\
Achromatopsia \\
Adult vitelliform macular dystrophy \\
Alström syndrome \\
Bardet-Biedl syndrome \\
Best disease \\
Choroideremia \\
Cone dystrophies \\
Fundus flavimaculatus \\
Juvenile macular dystrophy \\
Leber congenital amaurosis \\
Retinal dystrophy \\
Retinitis pigmentosa (RP) \\
Sorsby macular dystrophy \\
Stargardt disease/macular dystrophy \\
Usher syndrome \\
Technology type \\
Advanced (regenerative) therapies \\
Gene therapy \\
Medical device \\
Medical technology (medtech) \\
Pharmaceuticals/drugs \\
Purpose \\
Slow/stop disease progression \\
Reverse sight loss \\
Restore sight/vision \\
Timeframe \\
New \\
Emerging \\
\hline
\end{tabular}

5 regenerative and cell therapies. A further 11 technologies (Table 4) were identified in very early phases of development (typically phase I or pre-clinical) and were included in the final report to give a complete picture of developments 'on the horizon'. The vast majority of technologies identified are being developed by commercial developers, often collaborating with research groups within universities or other research institutions. We did not identify any one particular developer or group prominent in this area, although some commercial developers were developing more than one technology.

The majority of the technologies identified are in, or anticipated to be entering, clinical trials. The most advanced in terms of clinical trial phase are gene transfer AAV2-hRPE65v2 (technology 2) and Rescula (isopropyl unoprostone; Sucampo, Bethesda, MD, USA) eye drops (technology 23), which are both in phase III trials; Renexus (Neurotech USA, Cumberland, RI, USA; NT-501) implant (technology 25) has completed a phase II/III trial with reported outcomes; and human embryonic stem cell (hESC) derived retinal pigment epithelium (RPE) cells (technology 26) is currently in a phase II/III trial. Three medical devices: Alpha IMS Implant (Retina Implant AG, Reutlingen, Germany),
ARGUS II (Second Sight, Sylmar, CA, USA) and OkuStim (Okuvision $\mathrm{GmbH}$, Reutlingen, Germany; technologies 10, 11, and 17) are CE marked and available in the UK, although not widely diffused.

Specific IRDs for which treatments are being developed are shown in Table 5. Retinitis pigmentosa, the commonest IRD, is the focus of developments across all technology groups. Some technologies are in development for more than one condition (technologies 21,22,25,27, and 29).

\section{Expert input}

Clinical experts provided comment on 30 of the 40 technologies. Experts were able to provide more detailed comments on technologies more advanced in terms of trial phase. They were able to give useful insights into the potential impact of the technology, trial status, and probable timeframe for the technology.

Gene-based therapies were thought to have potential to improve retinal function or slow retinal degeneration, but clinical trials of these technologies are at an early stage and longer term follow-up is needed to determine whether the treatment is effective. The trials for gene replacement therapy for retinal disease caused by mutations in RPE65 have demonstrated that gene replacement therapy is safe and can improve retinal function, but may not prevent progressive retinal degeneration. ${ }^{9-11}$ One expert commented that the uptake in the NHS will be a key step if gene therapy is going to impact on patients with pressure for patients to be referred to major specialist centres. Experts questioned whether these technologies would meet the National Institute for Health and Care Excellence (NICE) cost-utility criteria.

Overall, there was less input on medical technologies. Two experts preferred to comment on medical technologies as a group rather than as individual technologies. Experts had mixed views on the Okustim System (technology 17). One expert thought it had little scientific basis, whereas another thought it was innovative and cutting edge. Both agreed that more results from clinical trials were needed. There were doubts from experts whether the Smart-Glasses (Assisted Vision, Oxford Smart Specs, Oxford, UK; technology 19) would be used regularly and it was thought that the PRIMA (Micro Photovoltaic Retinal Implant Array) implant (technology 18) needed further results before it could be determined if it would work.

Experts provided views on the individual pharmacological technologies in development. There was a question on the efficacy of brimonidine (technology 20) considering that when given topically there is no evidence that it has a protective effect in retinitis pigmentosa. It was commented that work in mouse models suggest that inhibitors of the visual cycle such as fenretinide 
Table 3 Review findings

\begin{tabular}{|c|c|c|c|}
\hline Technology name & Patient group & Developer & $\begin{array}{l}\text { Stage of development } \\
\text { eg, clinical trial phase }\end{array}$ \\
\hline \multicolumn{4}{|l|}{ Gene therapy } \\
\hline Gene Therapy AAV.REP1 & Choroideremia & Nightstar & Phase I/II \\
\hline Gene transfer AAV2-hRPE65v2 & $\begin{array}{l}\text { Leber congenital amaurosis } \\
\text { (LCA2) }\end{array}$ & Spark Therapeutics & Phase III \\
\hline $\begin{array}{l}\text { Gene Therapy AAV2/2- } \\
\text { hRPE65p-hRPE65 }\end{array}$ & Leber congenital amaurosis & $\begin{array}{l}\text { The University College London, } \\
\text { Moorfields Eye Hospital, AmpliPhi } \\
\text { Biosciences (formerly Targeted Genetics) }\end{array}$ & Phase I/II \\
\hline \multirow{2}{*}{\multicolumn{4}{|c|}{ Gene therapy rAAV2-CB-hRPE65 }} \\
\hline & & & \\
\hline \multicolumn{3}{|l|}{ Gene therapy (RPE65 mutation) } & Phase I/II \\
\hline $\begin{array}{l}\text { Gene therapy rAAV2-CBSB- } \\
\text { hRPE65 }\end{array}$ & Leber congenital amaurosis & The University of Pennsylvania & Phase I/II \\
\hline $\begin{array}{l}\text { Gene therapy rAAV2-VMD2- } \\
\text { hMERTK }\end{array}$ & $\begin{array}{l}\text { Retinitis pigmentosa (due to } \\
\text { MERTK mutations) }\end{array}$ & King Khaled Eye Specialist Hospital & Phase I/II \\
\hline $\begin{array}{l}\text { Gene replacement-UshStat; } \\
\text { StarGen; MY07A }\end{array}$ & $\begin{array}{l}\text { Retinitis pigmentosa } \\
\text { associated with Usher } \\
\text { Syndrome Type } 1 \mathrm{~B}\end{array}$ & Sanofi, Oxford BioMedica & Phase I/II \\
\hline $\begin{array}{l}\text { StarGen using LentiVector } \\
\text { technology to deliver a healthy } \\
\text { copy of the ABCR gene }\end{array}$ & Stargardt macular dystrophy & Sanofi, Oxford BioMedica & Phase I/II \\
\hline \multicolumn{4}{|l|}{ Medical technologies } \\
\hline Alpha IMS implant & Retinitis pigmentosa & Retina Implant AG & $\begin{array}{l}\text { CE marked and } \\
\text { available; subject to } \\
\text { ongoing phase I/II trial }\end{array}$ \\
\hline $\begin{array}{l}\text { ARGUS II Retinal Prosthesis } \\
\text { System }\end{array}$ & Retinitis pigmentosa & Second Sight & $\begin{array}{l}\text { CE marked and } \\
\text { available }\end{array}$ \\
\hline High-Acuity device & Retinitis pigmentosa & Bionic Vision & Not yet CE marked \\
\hline Wide-View device & Retinitis pigmentosa & Bionic Vision & Not yet CE marked \\
\hline $\begin{array}{l}\text { Bionic Eye Technologies } \\
\text { Retinal Prosthesis }\end{array}$ & Retinitis pigmentosa & The Boston Retinal Implant Project & $\begin{array}{l}\text { Clinical study planned } \\
\text { starting in } 2014\end{array}$ \\
\hline Image Processing Retinal & Retinitis pigmentosa & University of Bonn, Intelligent Implants & In clinical trials \\
\hline Implant System (EPI-RET Project) & & $\mathrm{GmbH}$ & \\
\hline IRIS2 System & Retinitis pigmentosa & Pixium Vision S.A. & $\begin{array}{l}\text { Patient testing in 2014, } \\
\text { and CE mark expected } \\
\text { during } 2015\end{array}$ \\
\hline $\begin{array}{l}\text { Okustim System -Transcorneal } \\
\text { Electrical Stimulation (TES) }\end{array}$ & Retinitis pigmentosa & Okuvision $\mathrm{GmbH}$ & $\begin{array}{l}\text { CE marked and } \\
\text { available for research } \\
\text { use in the UK }\end{array}$ \\
\hline $\begin{array}{l}\text { PRIMA (Micro Photovoltaic } \\
\text { Retinal Implant Array) }\end{array}$ & Retinitis pigmentosa & $\begin{array}{l}\text { Pixium Vision S.A. with Stanford } \\
\text { University }\end{array}$ & In clinical trials \\
\hline $\begin{array}{l}\text { Smart-Glasses (depth based } \\
\text { visual aid); Oxford Smart Specs }\end{array}$ & Impaired vision & $\begin{array}{l}\text { Assisted Vision, Oxford Smart Specs } \\
\text { Research Group }\end{array}$ & Patient testing ongoing \\
\hline \multicolumn{4}{|l|}{ Pharmacological technologies } \\
\hline $\begin{array}{l}\text { Brimonidine Intravitreal } \\
\text { Implant }\end{array}$ & Retinitis pigmentosa & Pfizer (originator); Allergan (licensee) & Phase I/II \\
\hline $\begin{array}{l}\text { Fenretinide (RT-101)-inhibitor } \\
\text { of vitamin A delivery to RPE }\end{array}$ & $\begin{array}{l}\text { Dry age-related macular } \\
\text { degeneration (AMD); } \\
\text { Stargardt macular dystrophy }\end{array}$ & ReVision Therapeutics & Phase II \\
\hline $\begin{array}{l}\text { QLT091001 (oral); synthetic } \\
\text { retinaldehyde }\end{array}$ & $\begin{array}{l}\text { Leber congenital amaurosis } \\
\text { (LCA) or RP due to RPE65 or } \\
\text { LRAT deficiency }\end{array}$ & QLT & Phase I/II \\
\hline $\begin{array}{l}\text { Rescula (isopropyl } \\
\text { unoprostone); Ocuseva } \\
\text { eye drops }\end{array}$ & Retinitis pigmentosa & $\begin{array}{l}\text { Sucampo Pharma Europe Ltd, RTech Ueno } \\
\text { Ltd }\end{array}$ & Phase III \\
\hline Valproic Acid (VPA); oral & Retinitis pigmentosa & $\begin{array}{l}\text { Foundation Fighting Blindness Clinical } \\
\text { Research Institute }\end{array}$ & Phase II \\
\hline
\end{tabular}


Table 3. (Continued)

\begin{tabular}{|c|c|c|c|}
\hline Technology name & Patient group & Developer & $\begin{array}{l}\text { Stage of development } \\
\text { eg, clinical trial phase }\end{array}$ \\
\hline \multicolumn{4}{|l|}{ Regenerative and cell therapies } \\
\hline $\begin{array}{l}\text { Renexus NT-501 ciliary } \\
\text { neurotrophic factor (CNTF) } \\
\text { implant }\end{array}$ & $\begin{array}{l}\text { Retinitis pigmentosa (early } \\
\text { and late stage); Usher } \\
\text { Syndrome; choroideremia }\end{array}$ & Neurotech USA, Inc. & $\begin{array}{l}\text { Completed phase II/III } \\
\text { trial and reported } \\
\text { outcomes }\end{array}$ \\
\hline $\begin{array}{l}\text { Human embryonic stem cell } \\
\text { derived retinal pigment } \\
\text { epithelium (RPE) cells }\end{array}$ & Stargardt macular dystrophy & Advanced Cell Technology & Phase II/III \\
\hline $\begin{array}{l}\text { Human embryonic stem cell } \\
\text { derived retinal pigment } \\
\text { epithelium (RPE) cells }\end{array}$ & Retinitis pigmentosa; AMD & $\begin{array}{l}\text { London Project to Cure Blindness, IRIS } \\
\text { UCL in collaboration with Pfizer }\end{array}$ & Clinical trial is planned \\
\hline ReN003 programme (stem cell) & Retinitis pigmentosa & ReNeuron & Phase I/II \\
\hline $\begin{array}{l}\text { Stem Cell Ophthalmology } \\
\text { Treatment Study (SCOTS) }\end{array}$ & $\begin{array}{l}\text { Retinal diseases (and optic } \\
\text { nerve) macular degeneration }\end{array}$ & Retinal Associates of South Florida & Phase I/II \\
\hline
\end{tabular}

Table 4 Technologies identified in the very early stages of development

\begin{tabular}{|c|c|c|c|}
\hline Technology name & Patient group & Developer & $\begin{array}{l}\text { Stage of development } \\
\text { eg, clinical trial phase }\end{array}$ \\
\hline $\begin{array}{l}\text { ACU-4429; Emixustat } \\
\text { Hydrochloride }\end{array}$ & $\begin{array}{l}\text { AMD; therapeutic potential for } \\
\text { Stargardt macular dystrophy }\end{array}$ & Acucela & $\begin{array}{l}\text { In trials for AMD at } \\
\text { present }\end{array}$ \\
\hline ALK-001 & $\begin{array}{l}\text { Therapeutic potential for Stargardt } \\
\text { macular dystrophy }\end{array}$ & Alkeus Pharmaceuticals & Phase I \\
\hline Altered form of vitamin A & Stargardt macular dystrophy & Columbia's Harkness Eye Institute & Pre-clinical \\
\hline $\begin{array}{l}\text { Engineered virus for gene } \\
\text { therapy delivery }\end{array}$ & Retinitis pigmentosa & The University of California at Berkeley & Pre-clinical \\
\hline $\begin{array}{l}\text { Glial cell and retinal } \\
\text { progenitor cells in retina } \\
\text { repair }\end{array}$ & Retinal diseases & The University of Washington & Pre-clinical \\
\hline Nanoparticle gene therapy & Retinitis pigmentosa & $\begin{array}{l}\text { Department of Cell Biology, The University of } \\
\text { Oklahoma Health Sciences Center }\end{array}$ & Pre-clinical \\
\hline NS2 eye drop & $\begin{array}{l}\text { Therapeutic potential for Stargardt } \\
\text { macular dystrophy }\end{array}$ & Aldexa & $\begin{array}{l}\text { Completed Phase I } \\
\text { trial }\end{array}$ \\
\hline Optogenetic therapy & Retinitis pigmentosa & NA & Pre-clinical \\
\hline $\begin{array}{l}\text { Photoreceptor } \\
\text { transplantation-embryonic } \\
\text { stem cells }\end{array}$ & Retinal diseases & $\begin{array}{l}\text { The UCL Institute of Ophthalmology and } \\
\text { Moorfields Eye Hospital }\end{array}$ & Pre-clinical \\
\hline $\begin{array}{l}\text { Piezoelectric inkjet (or '3D') } \\
\text { printer }\end{array}$ & Glaucoma (currently) & The University of Cambridge & $\begin{array}{l}\text { Pre-clinical; proof- } \\
\text { of-principle }\end{array}$ \\
\hline VSM 20R & $\begin{array}{l}\text { Therapeutic potential for Stargardt } \\
\text { macular dystrophy }\end{array}$ & Visium & Pre-clinical \\
\hline
\end{tabular}

(technology 21) may be of value in Stargardt macular dystrophy. There was a view that isopropyl unoprostone (technology 23) may not show an effect in trials, as trials of neurprotective agents are difficult to do because of patient numbers and the long-term follow-up required. The phase II trial of valproic acid (technology 24) was said to be based on limited animal work. The expert was pessimistic about the outcome.

Regenerative and cellular therapies identified in phase II/III clinical trials were Renexus (NT-501) (technology 25) and hESC-derived RPE cells (technology 26). Expert opinion was that Renexus would be unlikely to be developed as a treatment due to disappointing trial results. There were also doubts about hESC-derived RPE cells for Stargardt macular dystrophy. A safety study has demonstrated it to be safe in the short term, but the expert doubted the clinical effectiveness, as the vast majority of patients with Stargardt macular dystrophy who may benefit from stem cell therapy need replacement of both RPE cells and photoreceptors and this technology only replaces RPE cells. The other regenerative technologies were in phase I/II trials. Although the expert commented that 'cell replacement therapy holds out great hope', this was accompanied with a cautious note that 'much more pre-clinical work in animal models is needed'. 
Table 5 Specific IRDs subject to clinical trials

\begin{tabular}{ll}
\hline Technology group & IRDs in clinical trials \\
\hline Gene therapy & $\begin{array}{l}\text { Choroideremia } \\
\text { Leber congenital amaurosis } \\
\text { Retinitis pigmentosa (RP) due to } \\
\text { MERTK mutations } \\
\text { RP associated with Usher Syndrome } \\
\text { Type 1B }\end{array}$ \\
& Stargardt macular dystrophy \\
& Retinitis pigmentosa \\
Medical technology & Leber Congenital Amaurosis \\
Pharmacological & Retinitis pigmentosa \\
& RP due to RPE65 or LRAT deficiency \\
& Stargardt macular dystrophy \\
& (therapeutic potential) \\
Choroideremia \\
Retinitis pigmentosa \\
Regenerative and cell \\
Sherapy & Stargardt macular dystrophy \\
& Usher Syndrome
\end{tabular}

Some of the technologies in earlier development were thought by the experts to have a good scientific basis, but need to be assessed in clinical trials (technologies 30, 31, and 36).

\section{Patient and carer focus group input}

The focus groups commented on seven of the technologies. They thought that the Alpha IMS implant (technology 10) was an innovative and interesting development. The Okustim System (technology 17) stood out to some as it is believed to be already available and improves function, but currently has to be paid for. Others thought it sounded 'nice and simple', so were attracted to it, assuming it gives good improvement to sight. The groups were unsure whether they would want to wear video gaming goggles in public (PRIMA, Pixium Vision, Paris, France; technology 18). There was some excitement for NT-501 (technology 25) as a development and the fact that it is a later phase of development than some technologies.

However, there was some concern that another regenerative technology ReN003 (ReNeuron, Guildford, Surrey, UK; technology 28) uses non-embryonic tissue. It was felt that this may limit its use and that more could be done if embryos had been the source of stem cells.

\section{Discussion}

Currently, there is no cure or specific treatment for IRDs. However, a number of commercial developers and academic research groups are presently working on multiple avenues of intervention, including correcting the underlying defect, regenerating damaged retinal cells, preventing further retinal deterioration, providing artificial methods of sensing light, or improving assistive technologies. Some of these are in early clinical trials. Experts indicate that some of these developments are more applicable to the earlier stages of disease before significant retinal deterioration, such as gene therapy, while others are more applicable to advanced stages of the disease, such as artificial vision and stem cell therapy. These treatments are not mutually exclusive and may be complementary, potentially used either together or sequentially.

Many of these identified technologies are invasive treatments that involve subretinal injections, implants, and associated procedures (often involving complex surgery). There are risks generally associated with these treatments such as infection, damage to local structures, and inflammation, all of which have the potential to worsen any remaining vision. The patient and carer focus groups commented that people who had not yet lost their sight would be keen to have detailed information about the possible risks and complications for each new treatment so they can decide whether the potential benefits are worth it. They indicated that any remaining vision is precious so they would not want to do anything that risked damage and further loss of vision. However, most treatments in development will be offered to only one eye, usually the worst affected, and as the disease is symmetrical in most genetic eye disease the risk to sight loss is to some extent ameliorated. Note that an exception to this is the current phase III of gene transfer AAV2-hRPE65v2 (technology 2), where the technology is being used to treat both eyes.

\section{Developments in medical technologies}

Most of the developments in medical technology are implants that sit either on the retinal surface (technologies 11,15 , and 16) or underneath the retina (technologies 10 and 14), with some using an external camera on a spectacle frame linked to the implant to enable vision (for example, ARGUS II, technology 11), while another incorporates light-sensitive photodiodes (Alpha IMS, technology 10). There are two technologies CE marked and commercially available: the ARGUS II and the Alpha IMS. The focus groups commented that the appearance of technologies was important to younger people in particular. They suggested that appearance should be part of any technology design from the start. One woman said that even carrying a white stick had been a 'barrier to cross' as it made her feel noticeably different from other people. The patient focus groups suggested that even where a technology is effective, if people do not wish to wear the new device because of its appearance it will never be fully adopted. For example, some doubts were expressed over whether the PRIMA (technology 18) would be practical and acceptable as it means wearing 'gaming' style goggles. 
Clinical experts commented that most of the devices identified are for patients with advanced and end stage disease-patients who have lost the majority of their photoreceptors and have minimal vision. What these devices rely on is the observation that nerve fibres of the retina are still intact and can be stimulated directly to give some form of vision. Users need training and support to help them to interpret the information transmitted to the visual cortex, which needs to be allowed for in planning services. These devices are not suitable for people with severe infantile onset retinal dystrophies who have never had sight. In addition, there remain some unanswered questions, including longterm biocompatibility (for example, conjunctival erosion, retinal detachments, increased intraocular pressure, and decreased retinal perfusion) and the long-term effects of chronic nerve fibre stimulation.

\section{Pharmacological developments}

The most advanced drug in development is Rescula (isopropyl unoprostone) eye drops (technology 23), which is currently in a phase III clinical trial. Of the five drugs in phase II or phase III development, three are in development for retinitis pigmentosa. On the more distant horizon, there are also multiple drugs in pre-clinical or phase I development for slowing/halting progression of Stargardt macular dystrophy (Table 4).

\section{Gene and regenerative therapies}

Clinical expert and patient opinion indicates that the technologies likely to have the most impact in the future are gene therapies, and regenerative and cell therapies. Gene therapy is more advanced in terms of clinical development and has the potential to slow retinal degeneration or improve retinal function. The retina, as a gene therapy target, has features that facilitate therapeutic interventions. ${ }^{12}$ There is good surgical access and the route of administration can be altered to enable targeting of either the inner retina (by intravitreal injection), or the outer retina and RPE, by subretinal injection. ${ }^{12}$ The blood-retina barrier separates the subretinal space from the blood supply, enhancing the prospects for effective gene therapy by relative protection from immunemediated damage. ${ }^{12}$ Current research is focusing on optimizing the adeno-associated virus (AAV) delivery vector to enhance gene expression (technologies 1-7), allow larger genes to be delivered, and increasing chances of the treatment successfully targeting either RPE or photoreceptor cells. ${ }^{13}$ Lentiviral vectors are also being investigated (technologies 8 and 9) and is the vector being used in clinical trials of gene therapy for retinitis pigmentosa associated with Usher syndrome Type $1 \mathrm{~B}$ and Stargardt macular dystrophy. ${ }^{12}$
Gene therapy has the potential for long-term efficacy following a single administration of a vector that could be much more cost effective than repeated drug administrations. The vast majority of IRDs result from mutations in photoreceptor-specific genes, and gene therapy research could expand the range of retinal disorders potentially amenable to this approach. However, gene therapy approaches are most suitable for treating disorders once the degenerative process has resulted in extensive retinal cell loss. In addition, there are retinal disorders that are not currently suitable for gene therapy. In later stage disease, visual loss results from the death of retinal neurons, rather than loss of function of retinal neurons seen in earlier stages of disease.

An alternative approach is to replace lost photoreceptors / RPE cells using cell transplantation. According to the clinical experts, transplantation of photoreceptor cells has shown promise in animal models.

The eye has several properties that also make it a suitable target for regenerative approaches, such as relative ease of access and relative isolation from other body systems. ${ }^{14}$ Stem cells have the ability to self renew, the capacity to differentiate into other more specialised cells and the potential to replace damaged or missing retinal cells. Studies suggest that stem cells have the capacity to regenerate lost photoreceptors and improve vision. ${ }^{15}$ The techniques used at present are still relatively new, but their applications and benefits may be broad in the future. Stem cell therapies are generally considered safe. However, a patient's immune system may recognize the transplanted cells as foreign and this can trigger an immune reaction that results in rejection of the new cells. Genetic techniques have continued to advance and new gene editing technologies may allow the gene defect to be corrected in the patient's own cells before being transplanted. ${ }^{16}$ This will avoid an immunological reaction as the patient's own cells will be used. There are also potential concerns regarding tumour formation and longer term human studies are needed to assess the true safety profile of such treatments. In addition, there are ethical concerns associated with the use of embryonic stem cells in research, which will need addressing before widespread implementation by health services. ${ }^{17}$

This review identified five regenerative and cell therapies. The most advanced of these in terms of clinical trials is Renexus (NT-501, technology 25). This consists of encapsulated human cells genetically modified to secrete ciliary neutrophic factor (CNTF), a growth factor that stimulates and protects neural cells. According to company information, Renexus is designed to continually deliver a safe and therapeutic dose of CNTF into the site of treatment. ${ }^{18}$ However, preliminary results in achromatopsia and retinitis pigmentosa have been 
disappointing and the experts felt that this is unlikely to be developed as a technology. ${ }^{19,20}$

\section{What this review adds}

This horizon scanning review summarises innovation in a disease area that has been previously underreported and has a significant negative impact on people's quality-oflife. Through working closely with Fight for Sight, the NIHR Horizon Scanning Centre has addressed the key question 'can a treatment to slow down progression or reverse sight loss in IRDs be developed?' cited in the Sight Loss and Vision PSP report. Identifying these technologies helps focus research funding on those developments that are showing promise, identifies gaps in research for some diseases that do not appear to be attracting attention, and introduces policy-makers to changes to service provision that may be required in the future. Fight for Sight have indicated they have used the horizon scanning review findings: to 'raise the profile for eye research to attract more funding into the arena' and alongside the JLA PSP 'to engage with the key funders of eye research to identify the gaps in research and where investment is needed'.

The incorporation of both clinical expert and patient views offers a rich perspective to horizon scanning reviews. Clinical experts, and patient and carer focus groups assisted with the review and provided a wide range of helpful information and insights, such as the availability of specialised services for patients, the potential impacts (positive and negative) of individual technologies on people with IRDs and their families, and helped to identify additional relevant technologies (particularly those in earlier phases of development). This engagement ensured that important areas of innovation were not missed. The focus groups in particular provided valuable insights into the technologies presented from potential user's perspective; however, the comments highlighted the hope that patients hold for some technology developments that may be still some way off or less likely to succeed. The focus groups also highlighted a number of concerns related to the future access to new treatments including:

- Many people with IRDs have been discharged from NHS care as they have conditions which are currently incurable and their management is focused on visual rehabilitation, support, and training delivered in community settings. This could make it difficult for these people to gain access to new treatments.

- There should be more attention paid to informing clinicians about new developments as and when they become available. There is some concern about availability of treatments/clinical trials being dependent on the awareness of the individual consultant and some people find it difficult to challenge their doctors to gain access to new treatments. At present, patients feel the onus is largely on them to find out about emerging treatments. ECLOs, patient groups, and charities should be made aware of newly available treatments as they become available on the NHS, so they can share the information more widely.

- There is a particular need for outreach workers to ensure that those of different cultures and ethnicities are included in developments and opportunities, especially for those conditions which are more prevalent in defined ethnic groups.

- New therapies and devices are likely to be expensive, and patients expressed concerns that novel treatments will only be made available to younger people, potentially ignoring the needs of older people.

- The 'hype' in the media about specific treatments can give false hope to people. For example, when a newspaper prints a story, people want to be part of a trial even though the research is at an early stage, often a long way from patient recruitment stage.

Although this is a time of unprecedented innovation for developing potential therapies for IRDs, most of the health technologies identified in this review are still at an early stage of development and it is difficult to estimate when treatments might be available in the clinic. Further, well designed trials that generate data on efficacy, applicability, acceptability, and costs of the technologies, as well as the long-term impacts for various conditions are required before these can be considered for adoption into routine clinical practice.

\section{Conflict of interest}

Professor ATM is a Chairman of the data safety and management committee for the Oxford Biomedica and Sanofi gene therapy trials and is a consultant to Sanofi and Succampo. He has been an advisor to QLT and is involved in their current trial of oral retinoids for retinal dystrophies.

\section{Acknowledgements}

The NIHR Horizon Scanning Centre wishes to thank the clinical experts who assisted in the review, and the members and facilitators of the patient and carer focus groups and Fight for Sight.

\section{Disclaimer}

This report presents independent research funded by the National Institute for Health Research (NIHR). The views 
expressed in this publication are those of the authors and not necessarily those of the National Health Service, the NIHR or the Department of Health.

\section{References}

1 Sundaram V, Moore AT, Ali RR, Bainbridge JW. Retinal dystrophies and gene therapy. Eur J Pediatr 2012; 171(5): 757-765.

2 RP Fighting Blindness. Other Inherited Retinal Conditions. http://www.rpfightingblindness.org.uk/index.php?tln= aboutrp\&pageid $=66$.

3 Moore T, Burton H. Genetic Ophthalmology in Focus: A Needs Assessment and Review of Specialist Services for Genetic Eye Disorders PHG Foundation 2008. Available at http://www.phgfoundation.org/pages/work2.htm.

4 Liew G, Michaelides M, Bunce C. A comparison of the causes of blindness certifications in England and Wales in working age adults (16-64 years), 1999-2000 with 20092010. BMJ Open 2014; 4: e004015.

5 Rahi JS, Cable N. British Childhood Visual Impairment Study Group. Severe visual impairment and blindness in children in the UK. Lancet 2003; 362: 1359-1365.

6 Patient: trusted medical information and support. Hereditary retinal dystrophies. Available at http:/ / www. patient.co.uk/doctor/Hereditary-Retinal-Dystrophies.htm.

7 Rowe F, Wormald R, Cable R, Acton M, Bonstein K, Bowen $\mathrm{M}$ et al. The Sight Loss and Vision Priority Setting Partnership (SLV-PSP): overview and results of the research prioritisation survey process. BMJ Open 2014; 4(7): e004905.

8 EuroScan International Network. EuroScan International Network. A toolkit for the identification and assessment of new and emerging technologies, 2014. Birmingham: Euroscan International Network. Available at http:// euroscan.org.uk/methods.

9 Bennett J, Ashtari M, Wellman J, Marshall KA, Cyckowski LL, Chung DC et al. AAV2 gene therapy readministration in three adults with congenital blindness. Sci Transl Med 2012; 4(120): 120ra15.

10 Jacobson SG, Cideciyan AV, Ratnakaram R, Heon E, Schwartz SB, Roman AJ et al. Gene therapy for leber congenital amaurosis caused by RPE65 mutations: safety and efficacy in 15 children and adults followed up to 3 years. Arch Ophthalmol 2012; 130(1): 9-24.

11 Bainbridge JW, Smith AJ, Barker SS, Robbie S, Henderson R, Balaggan K et al. Effect of gene therapy on visual function in Leber's congenital amaurosis. N Engl J Med 2008; 358(21): 2231-2239.
12 McClements M, Maclaren RE. Gene therapy for retinal disease. Transl Res 2013; 161(4): 241-254.

13 McGrath D. Inherited Retinal Disease: Current Research is Focusing on Optimising the AV Delivery Vector to Enhance Gene Expression. Available at www.nets.nihr.ac.uk/ identifying-research/james-lind-alliance.

14 Borooah S, Phillips MJ, Bilican B, Wright AF, Wilmut I, Chandran $\mathrm{S}$ et al. Using human induced pluripotent stem cells to treat retinal disease. Prog Retin Eye Res 2013; 37: 163-181.

15 Huang Y, Enzmann V, Ildstad ST. Stem cell-based therapeutic applications in retinal degenerative diseases. Stem Cell Rev 2011; 7(2): 434-445.

16 Zheng A, Li Y, Tsang SH. Personalized therapeutic strategies for patients with retinitis pigmentosa. Expert Opin Biol Ther 2015; 15: 391-402.

17 The Wellcome Trust. The Wellcome Trust. The ethics of stem cells. Available at http://www.wellcome.ac.uk/About-us/ Policy/Spotlight-issues/Human-Fertilisation-andEmbryology-Act/Stem-cell-basics/WTD040077.htm.

18 Neurotech. NT-501 CNTF Renexus. Available at http://www.neurotechusa.com/cntfrenexus.html. Accessed January 2015.

19 Zein WM, Jeffrey BG, Wiley HE, Turriff AE, Tumminia SJ, Tao W et al. CNGB3-achromatopsia clinical trial with CNTF: diminished rod pathway responses with no evidence of improvement in cone function. Invest Ophthalmol Vis Sci 2014; 55(10): 6301-6308.

20 Birch DG, Weleber RG, Duncan JL, Jaffe GJ, Tao W. Ciliary Neurotrophic Factor Retinitis Pigmentosa Study Group. Randomized trial of ciliary neurotrophic factor delivered by encapsulated cell intraocular implants for retinitis pigmentosa. Am J Ophthalmol 2013; 156(2): 283-292.e1.

(c) (1) () $\Theta$ This work is licensed under a Creative Commons Attribution-NonCommercial-

NoDerivs 4.0 International License. The images or other third party material in this article are included in the article's Creative Commons license, unless indicated otherwise in the credit line; if the material is not included under the Creative Commons license, users will need to obtain permission from the license holder to reproduce the material. To view a copy of this license, visit http://creativecommons.org/licenses/by-nc-nd/4.0/ 